
mojca.jarc@fdv.uni-lj.si

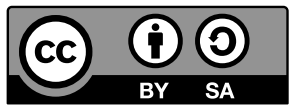

\title{
MULTILINGUAL GENRE PRACTICES IN INTERNATIONAL RELATIONS
}

\section{INTRODUCTION}

Globalisation has produced not only denser, but also linguistically more complex communication networks. Multilingual interactions are increasingly becoming part of the everyday routines of millions of people. This change can also be observed in educational, and professional settings. Being able to explore and develop one's linguistic potential therefore seems to be a conditio sine qua non to effectively integrate in a discourse community, and to fully participate in it.

However, the process of enhancing fruitful conditions for such development has been accompanied by socio-political, economic, educational and didactic concerns raising, among other issues, questions of language diversity, language dominance, language education, and language policies. An ample literature reports on the difficult management of multilingual situations in these fields (e.g. Blommaert, Collins and Slembrouck 2005; Canagarajah 2007; 2018; Franceschini 2011).

The complexity of linguistically diverse communities is reflected in different perceptions of multilingualism. A more traditional way of viewing multilingualism as a personal micro-condition was rooted in structuralism, and in the conception of languages as cognitively separate structures. To breach the gap between the personal and social conditions of using many languages, both research and teaching practices have made a sometimes useful distinction between multilingualism and plurilingualism. It is in this vein that the CEFR opposes multilingualism, which can be understood as "coexistence of different languages", to the plurilingual approach, which emphasises that as an individual person's experience of language in its cultural contexts expands, from the language of the home to that of society at large and then to the languages of other peoples (whether learnt at school or college, or by direct experience), he or she does not keep these languages and cultures in strictly separated mental compartments, but rather builds up a communicative competence to which all knowledge and experience of language contributes and in which languages interrelate and interact. (Council of Europe 2001: 4). 
This essentially cognitively-based vision of plurilingual competence was complemented by a more socially-based line of thought, which brought forward the conceptualisation of multilingualism ${ }^{1}$ as an affordance of an environment, in which acculturation takes place (Blommaert, Collins and Slembrouck 2005).

The implementation of tertiary level course programmes that take into account students' multilingual communication needs has been a difficult task. LSP (language for specific purposes) teaching and its ramifications (language for academic purposes, language for academic and specific purposes) have played a crucial part in the acculturation efforts of novice students and researchers, with different types of scaffolding envisaged to cater to their language needs. In the last thirty years, many higher education programmes chose the apparently more comfortable option of English as a medium of instruction (EMI), neglecting other languages and producing an excessive focus on the use of English language learning/teaching (Chang 2019). Additionally, a sharper focus on the study of genre practices in academic and professional environments was called for (Bhatia 2008).

As opposed to the EMI, alternative approaches take into account different personal circumstances of LSP students and reinforce their plurilingual profiles by fostering their existing language repertoires, strengthening their multicultural awareness, as well as the awareness of genre cultures (Moore and Gajo 2009; Meyer et al. 2012; Galante et al. 2019).

The present study offers a genre-based perspective on International Relations (IR) as a discipline. We seek to examine the genre practices of IR community members in academic and professional settings. IR students studying in undergraduate and postgraduate programmes typically face the challenges of multilingualism in their everyday routines. Moreover, graduates transitioning to professional life in the IR field often work within multilingual discourse communities. Our main aim is to add to a growing body of systematic research into the genre practices of different professional fields, particularly to shed light on the multilingual character of these practices.

The literature review in the next section is followed by a presentation of the study, its participants, and results. We continue by analysing the findings and their implications for LSP theory and practice. In the conclusion, we identify the limitations of our study and pose some questions for future research.

\subsection{Genre theories and practices}

Genre practices have been recognised as an important driver of language teaching. Genrebased teaching and research have mostly developed in English speaking countries. Hyon (1996) distinguishes three genre traditions: ESP (English for Specific Purposes), Systemic

1 Remaining aware of the CEFR differentiation, we use the term multilingualism to refer to the use of more than one language in a given discourse community, i.e. the IR community. 
Functional Linguistics, and North-American Rhetoric, and these traditions gradually started to converge. What the three genre theories have in common is that they all view genre as a social phenomenon transcending the limits of texts. They analyse the textual features of genres as representations of social activities, concentrating on the functional characteristics of discourse within a given discourse community (Swales 1990). The theorisation of genre thus moves beyond the study of literary texts and encompasses different kinds of recurring typified expression, such as academic and professional texts (Bhatia 2008), or even other types of human activities, such as architectural works or music (Frow 2006).

According to genre theories, members of a discourse community use genres as a response to the requirements of this community. In order to be able to produce such a response, they have to know how a genre is conventionally formed and what type of aims they are trying to achieve with it, e.g. doctors have to learn how to write medical records in order to facilitate medical care.

A discourse community can use more than one genre to achieve its recognisable aims and objectives. The genres of a community form a system, reflecting culturally conditioned social activities. Members of a community should thus be acquainted with groups of connected genres. These groups are referred to as genre repertoires (Orlikowski and Yates 1994), systems of genres (Bazerman 1994), genre sets (Devitt 2004), disciplinary genres (Bhatia 2004), or genre ecologies (Spinuzzi 2004). As shown by Spinuzzi (2004), each or these terms highlights different aspects of genre practices, relations among genres, and genre participants, and foregrounds different genres. In contrast with the other terms mentioned, the term genre ecology emphasises the intermediary function of genres, which means that genres are seen not only as tools used by a community member, but as units, bearing a mediational role in genre practices. This allows the researchers to focus on both official and unofficial genres, as well as on the dynamic use of genres. ${ }^{2}$

\subsection{Analysing genre practices}

Research into genres has employed a range of methodological approaches, reflecting the concerns of genre users and LSP practitioners. This has produced a continuum with context-oriented studies into genre practices on the one side, and text-oriented studies on the other side. While the socially focused studies commonly rely on qualitative methodologies, using participant observation, interviews, or diary writing, the studies examining the textual features (e.g. lexico-grammatical patterns) use quantitative methods (Hyland 2004).

Much of the ESP teaching and research focused on individual high stake genres, e.g. academic articles. On the other hand, a more socially based vein of genre analysis

2 Following Spinuzzi (2004), we use the expression genre repertoire to refer to a set of genres used by an individual member of the IR community, and the expression genre ecology to refer to the interaction between genres in the community. 
brought forward the observation that genres are rarely used in isolation (Bawarshi and Reiff 2010). Genre mapping is a method used to systematically record genres of a given professional, academic or cultural field (Chitez and Kruse 2012), although such studies are relatively rare.

The scarcity of genre mapping studies in multilingual communities could be attributed to the complexity of such analyses, but existing studies, that were mainly carried out in Europe, show that this kind of research can be very informative for programme designers, because it offers information which would be difficult to access through other methods. Using contrastive genre mapping, Kruse and Chitez (2012) compared genre practices at three Swiss universities based in Italian, German and French language regions. This method allowed them to classify the collections of genres into genre families, and determine the similarities and differences between students' genre repertoires. Based on the findings, they described the characteristics of academic cultures in different regions. Lorenzo (2013) used the method of contrastive genre mapping to produce a multilingual genre map serving to organise a CLIL program in a Spanish secondary school, and calling for reinforced collaboration between language and content teachers.

Research into multilingual genre practices in an academic environment has predominantly focused on the difficulties faced by international students and researchers entering English-medium universities and producing English-medium texts. However, some studies on biliteracy processes strayed away from the focus on students' knowledge gaps and called for renewed research agendas, stressing also the opportunities for language transfer (Gentil 2011; Kim and Belcher 2018).

The uneven coverage of research into genre practices can also be observed with regard to different disciplines. Some professional fields have received relatively little attention by genre researchers. While research into multilingual practices in business environments is abundant (Mettewie and Van Mense 2009; Angouri 2014; Pierini 2016; Schlabach 2017), the IR field remains surprisingly under-researched, considering the high-stake genre practices that the members of this disciplinary community are involved into.

\section{2}

\section{THE STUDY}

The present study grew out of a larger project aiming to design a course in French for specific purposes (FSP), which would foster genre awareness among IR students at the Faculty of Social Sciences, University of Ljubljana. The participants in our study are all rooted in the University of Ljubljana, which is the biggest university in Slovenia. It could essentially be termed as a monolingual university with a strong ambition to internationalise. The IR programmes are offered at the Faculty of Social Sciences as part of undergraduate as well as postgraduate programmes. 
IR is a political science discipline, studying relations between states and other IR actors (i.e. entities that are recognised by international law). This complex subject matter has been conceptualised through many different theoretical approaches and competing paradigms (Roche 2001). It is a relatively 'young' academic discipline, and the first IR study programme in Great Britain was established in 1919 (Lebow 2008). Graduates in IR become employed in international governmental or non-governmental organisations, government services, media, international businesses, and so on. Proficiency in more than one foreign language along with intercultural and global awareness are among the key skills IR students are expected to develop. This goal is particularly important for students and professionals based in essentially monolingual communities, but working in international settings.

Given that language FL/L2 language teaching/learning in general and genre teaching/learning in LSP are always context-bound, we decided to investigate the nature of genre practices in the IR community. With a genre based analysis of the disciplinary practices we sought to understand how new and experienced members cope with genre repertoires and what type of problems they face in their acculturation processes.

\subsection{Research questions}

The overall aim of the present study was to determine the nature of genre repertoires, enacted by members of the IR community based in the Slovenian context. More particularly, we investigated into the types of genres commonly used by members, the languages in which those genres were enacted, and the development of genre practices at different stages of members' disciplinary trajectories. Our research was limited to written genres.

Our research questions were as follows:

$R Q 1$. Which written genres does the IR community use in academic and in professional contexts?

$R Q 2$. In which languages are these genres enacted?

$R Q 3$. How do the IR members' genre repertoires change?

\subsection{Research methods and procedures}

In the vein of a strong tradition of genre-based studies relying on ethnomethodological frameworks, we used qualitative research procedures. The advantage of this approach is that it enables insights into participants' definitions and perceptions of genre practices (Lillis 2013).

Our participants were all rooted in the University of Ljubljana. Candidates for our study were selected on the basis of their disciplinary identity and plurilingual repertoires. They were identified among the experienced and novice members of the IR academic and 
professional community. As the overall objective of the study was to use the data in the preparation of the FSP programme, we made sure that all of the participants use French as one of the languages in their academic/professional communication. Their personal plurilingual profiles showed that their plurilingual identity included three to seven languages. The data was collected between June 2014 and September 2015.

In the invitation email we explained the aim of our study. We asked the candidates to prepare a collection of typical written texts they use in their everyday academic/professional practice. We invited them to a semi-structured interview, in which they were able to speak about their genre practices. A total of 29 IR community members responded to our invitation.

The research involved several stages. Data gathering was a process that stretched over a longer period of time, allowing participants to collect types of texts they read or produced themselves, and to reflect on their practices. Subsequently, a semi-structured interview was carried out with each participant. The total length of the interviews was 33 hours and 34 minutes. The average length of the interview was 70 minutes. The first aim of the semi-structured interviews with members of the IR community was to determine the respective roles of individual genres in the genre repertoires, and to group genres according to their roles in genre ecologies. We guided the interviewees in their reflections on how they participate in their disciplinary community, what genres they use, in which languages these genres are enacted, and how their genre repertoires change over time. The broad topics of the interview were further narrowed down to suit the particular profile of the interviewee. The data was coded manually to search for patterns of genre use. Finally, we rechecked the results with triangulation of data retrieved in the programme descriptions and in the genre collections compiled by the participants. This procedure was applied to ensure reliability and representativeness.

\section{3}

\section{FINDINGS}

Our assumption was that culture with its ideological and material contexts influences the nature of the genres and contributes to the ability of community members to orient in time and space. Genres develop through the activities of a particular group and form patterns of behaviour that are accepted by the community. The community members are thus considered to be the most reliable observers and interpreters of genre practices. They are able to recognise a particular genre, to name it, and identify its characteristics (Devitt 2004).

This assumption lead us to choose the user approach to the observation of genre practices. It is from the genre collections of our participants and from their accounts of the genre practices, in which they participate, that we deduced the main characteristics of genre repertoires and the emerging themes regarding the specific nature of these repertoires. 


\subsection{Genre repertoires}

We asked our participants to collect and discuss those written genres they deemed the most common and pertinent in their current or past disciplinary practices.

The result of the genre mapping procedure in the first stage was a collection of 120 typical academic and professional genres in three languages. This vast and diversified cohort of texts was contextualised with some basic descriptors: the name, type of use (reading/writing) type of source, and languages in which the genre was produced. Each genre was described according to these descriptors. For a section of the inventory, related to genres in academic environment, see Table 1.

Table 1: Extract from IR genre repertoires - academic context.

\begin{tabular}{|l|l|l|}
\hline Genre & Type of use/Type of source & Language \\
\hline Research article & Reading, writing/Secondary source & English, Slovene, French \\
\hline Professional article & Reading, writing/Secondary source & English, Slovene, French \\
\hline Monograph & Reading, writing/Secondary source & English, Slovene, French \\
\hline Chapter in a monograph & Reading, writing/Secondary source & English, Slovene, French \\
\hline Textbook & Reading, writing/Secondary source & English, Slovene, French \\
\hline $\begin{array}{l}\text { Chapter in conference } \\
\text { proceedings }\end{array}$ & Reading, writing/Secondary source & English, Slovene, French \\
\hline Study materials & Reading, writing/Secondary source & English, Slovene, French \\
\hline News article & $\begin{array}{l}\text { Reading, writing/Secondary source, } \\
\text { student writing }\end{array}$ & English, Slovene, French \\
\hline International treaty & $\begin{array}{l}\text { Reading/Secondary source, student } \\
\text { writing }\end{array}$ & English, Slovene, French \\
\hline $\begin{array}{l}\text { Speech by a state } \\
\text { representative }\end{array}$ & $\begin{array}{l}\text { Reading, writing/Secondary source, } \\
\text { student writing }\end{array}$ & English, Slovene, French \\
\hline Comparative analysis & $\begin{array}{l}\text { Reading, writing/Secondary source, } \\
\text { student writing }\end{array}$ & English, Slovene, French \\
\hline Court decision & Reading/ Primary source & English, Slovene, French \\
\hline Newspaper article & $\begin{array}{l}\text { Reading, writing/Secondary source, } \\
\text { student writing }\end{array}$ & English, Slovene, French \\
\hline Seminar paper/Research & Writing, reading/Student writing & English, Slovene, French \\
\hline Project assignment & Writing, reading/Student writing & Slovene \\
\hline Lecture notes & Writing, reading/Student writing & English, Slovene, French \\
\hline Essay & Wrench \\
\hline
\end{tabular}




\begin{tabular}{|l|l|l|}
\hline Genre & Type of use/Type of source & Language \\
\hline Izpitni esej & Writing, reading/Student writing & Slovene \\
\hline Dissertation fr. (esej) & Writing, reading/Student writing & French \\
\hline Galop d'essai & Writing, reading/Student writing & French \\
\hline Dossier & Writing, reading/Student writing & French \\
\hline Fiche de lecture & Writing, reading/Student writing & French \\
\hline Synthèse & Writing, reading/Student writing & French \\
\hline Mémoire & Writing, reading/Student writing & French \\
\hline
\end{tabular}

As shown in Table 1, the social use of the collected genres can be related to the reading of sources and/or to writing. The academic users of IR sources distinguish between primary, secondary and tertiary sources. Primary sources are an object of research (e.g. speeches of state representatives are a primary source for researchers and for students, who would like to read the original IR documents). Secondary sources are outlets, in which the IR research is published (i.e. monographs, academic journals, etc.). Tertiary sources (i.e. handbooks, bibliographies, etc.) synthesise the disciplinary knowledge. Genres marked as 'student writing' are produced by students for educational purposes. Students are asked to produce these genres either as part of the knowledge and critical thinking development, or in the framework of assessment and evaluation processes.

The genre repertoires collected by our participants and the genres described in the interviews were compared by means of the descriptors. Based on the comparison, it was established that a single principal genre repertoire could not be determined because different types of genre users engaged in selected genres, and not in the whole range of available genres.

\subsection{Types of genre users}

Genre users enter an academic or professional discourse community with some prior genre knowledge. They build on this knowledge, reformulate, reshape and adapt it to integrate in the new discourse community (Norton 2013). Experienced users select among the disciplinary genres and participate in them to achieve their communicative purposes.

Six profiles of genre users emerged on the basis of the comparison of descriptors:

- Novice undergraduate students in the Slovene academic environment;

- Experienced undergraduate students in the Slovene academic environment;

- Graduate students in the Slovene academic environment;

- Exchange students in the French academic environment;

- Professors and researchers in the Slovene academic environment;

- IR graduates employed in international institutions, government services, nongovernmental organisations, and in internationally oriented businesses. 
This segmentation was to be expected, as the inventories of genres and types of use varied according to the roles, and according to the priorities of participants in the disciplinary community, e.g. novice undergraduate students mostly read secondary sources, while the more experienced members of IR community increasingly rely on primary sources.

The same division could be observed along the reception/production lines. Students, for example, usually act as readers of primary and secondary sources. Teachers of IR subjects and graduates employed in international institutions, on the other hand, can act at the same time as writers and readers of secondary or tertiary sources, sometimes also as contributors to primary sources.

However, the identified types of genre users are not always neatly delineated, because the interviewees can combine their activities in different institutional and linguistic contexts. Three instances of hybrid identities were observed: students combining academic and professional activities; exchange students; and academic staff combining teaching and research activities. The interviewees, who had to cope with a combination of contexts, reported that these mixed identities contributed to the diversification and enrichment of their genre repertoires. In many cases, such situations brought about new acculturation related challenges, gaps in genre knowledge and discontinuity in genre practices. The transition periods were particularly demanding in this respect. For example, exchange students, who spent a semester abroad, had to temporarily adapt their existing academic genre practices to the requirements of the host institution (Jarc 2015), without being able to transfer the newly acquired genre competence to their home institution.

\subsection{Genre families}

The roles of genres and types of users identified in the first stage of our research allowed us to move to the second stage of analysis. The aim of this stage was twofold: firstly, to group the genres into genre families, and secondly, to observe which gaps appeared in the process of acquiring genre knowledge as our interviewees found themselves in transition periods, either entering a new institutional and/or linguistic context. The biggest change in genre practices was observed when our interviewees moved from the academic to the professional contexts.

In the academic context, six genre families were identified: genres of student writing, primary sources, secondary sources, professional genres, journalistic genres, and 'new genres'. Genres were grouped into these families according to their communicative purpose and according to the source context. For examples of genres found in each of these families, see Table 2. 
Table 2: IR genre families - academic settings.

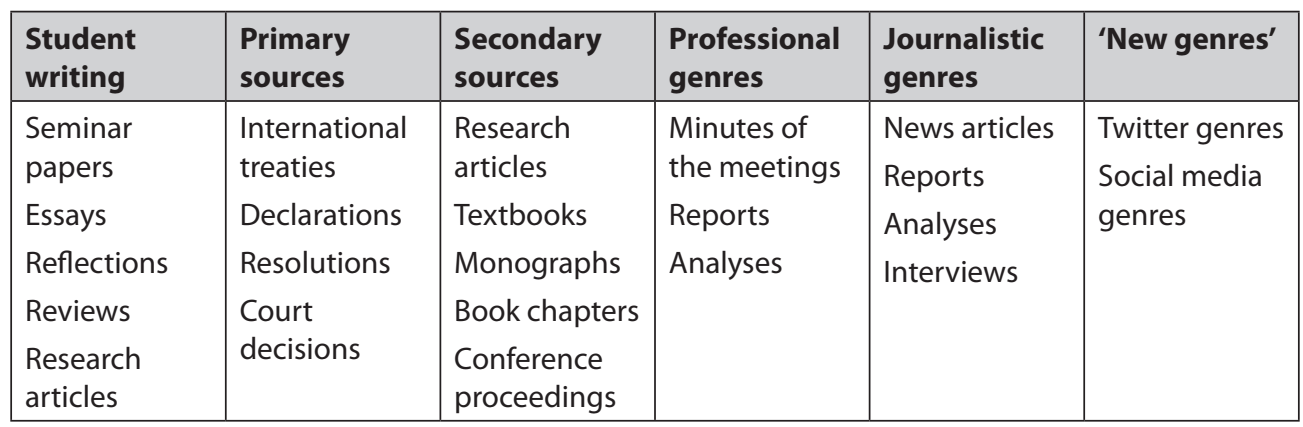

In professional settings, six genre families were also identified: job application genres, genres of diplomacy, academic genres, genres of internal communication, Public Relations (PR) genres, and field specific genres. For examples of genres found in each of these families, see Table 3 .

Table 3: IR genre families - professional settings.

\begin{tabular}{|c|c|c|c|c|c|}
\hline $\begin{array}{l}\text { Academic } \\
\text { genres }\end{array}$ & $\begin{array}{l}\text { Diplomacy } \\
\text { genres }\end{array}$ & $\begin{array}{l}\text { Internal } \\
\text { communication } \\
\text { genres }\end{array}$ & PR genres & $\begin{array}{l}\text { Job application } \\
\text { genres }\end{array}$ & $\begin{array}{l}\text { Field } \\
\text { specific } \\
\text { genres }\end{array}$ \\
\hline $\begin{array}{l}\text { Research } \\
\text { articles } \\
\text { Essays } \\
\text { Reflections } \\
\text { Reviews }\end{array}$ & $\begin{array}{l}\text { Diplomatic } \\
\text { notes } \\
\text { Wires } \\
\text { Genres of } \\
\text { diplomatic } \\
\text { protocol } \\
\text { Genres of } \\
\text { international } \\
\text { negotiations } \\
\text { Occluded } \\
\text { genres }\end{array}$ & $\begin{array}{l}\text { Memos } \\
\text { Minutes of the } \\
\text { meetings } \\
\text { Reports } \\
\text { Analyses } \\
\text { Action plans } \\
\text { Occluded genres }\end{array}$ & $\begin{array}{l}\text { Press releases } \\
\text { Prepared } \\
\text { speeches } \\
\text { Press kits } \\
\text { Reports } \\
\text { Brochures } \\
\text { Twitter genres } \\
\text { Social media } \\
\text { genres }\end{array}$ & $\begin{array}{l}\text { Job } \\
\text { advertisement } \\
\text { Application } \\
\text { letter } \\
\text { CV } \\
\text { Response to } \\
\text { an application } \\
\text { letter }\end{array}$ & $\begin{array}{l}\text { Genres } \\
\text { specific for a } \\
\text { given field } \\
\text { (e.g. genres } \\
\text { of European } \\
\text { institutions, } \\
\text { space law, } \\
\text { etc. ) }\end{array}$ \\
\hline
\end{tabular}

The main protagonists in the academic environment are teachers, researchers and students, who act either as writers or readers of the genres listed in the above families.

The first three groups of genres in Table 2 could be termed as curriculum genres. They were also identified in the course descriptions. A closer analysis of the curriculum genres shows that the recent developments of the academic practices brought some changes in the institutional preferences regarding the use of student writing genres and the secondary sources. If the generation of undergraduate novices studying for their exams some twenty years ago were mostly relying on monographs and book chapters, the 
younger generation today refers to research articles as the primary source of disciplinary knowledge. In the students' writing practices seminar paper remains the umbrella genre for different types of assignments, but it is increasingly being replaced by essay writing. What Table 2 does not show, because it could be detected only through interviews, are absences in this family. Namely, after the Bologna reform students are no longer required to write an undergraduate thesis, which had been considered as a key genre in the previous generation of interviewees.

The last three genre families in Table 2 indicate that not all the sources our interviewees referred to in their descriptions of genres were of an academic or educational nature. For instance, the need to be informed through different types of news articles, accessible either in the printed or online media, was often highlighted by our interviewees. This was required particularly when current IR events were analysed in the framework of course activities.

Another recent trend appeared in the last three genre families, namely a clear movement from 'pure academic genres', as one of our interviewees called them, to professional genres. This change could be explained by the efforts of higher education institutions to align with the orientations imposed by the Bologna reform. This document specifically called for more practically oriented higher education curricula, developing marketoriented skills to foster the employability of European graduates (European Commission 2009). But as explained by our interviewees, the so-called 'new genres' of the digital environment were not actively dealt with in the academic programmes. Since their introduction into IR practice at the national, supranational and international levels, the importance of these types of genres has been growing, which made the gap increasingly visible.

The proliferation of different genres represented a burden, not only to the students, but also to the IR graduates who participated in our interviews. Overall, they admitted that the genre knowledge they managed to build during their studies helped them better integrate in the professional community. However, they experienced some unexpected challenges regarding the genre requirements in the professional settings.

The first challenge was related to the para-professional genres of job application. Our interviewees regretted not having the opportunity to deal with them during the final year of their studies.

The second challenge was posed by the changed roles of genre users and the functions of workplace genres, which were modelled by the tasks performed by genre users. For some of the interviewees, the number of genres increased considerably when they left the academic setting. The broad range of genres our interviewees were daily involved in included combinations of regulation genres, analytical genres, administrative genres, organisational genres and promotional genres. Moreover, they were asked to communicate with the expert community members and with the general public.

Consequently, their genre repertoires became more diversified, more dependent on the workplace of the genre user, as well as on the place of the genre user in the 
institutional hierarchy. Rather than only writers and readers, our interviewees acted as interpreters of texts, evaluators, reviewers, negotiators, editors, reporters, researchers, members of multilingual teams, and even creators of new genres.

The third challenge was the instability of genre repertoires. In our interviewees' careers there were frequent shifts from one position to another, and consequently a complete change of workplace genre repertoires was not uncommon. These shifts required the ability to adapt, not only to the new genre repertoires, but also to the institutional contexts in which the genres were enacted. Through the regulation of genres, institutions determined the language(s) of communication, the values, rhetorical structure of genres, place of genres in the genre repertoires, communication channels, and participants in genre practices.

Finally, the genre families of workplace contexts were difficult to determine in more detail, because the genre practices of diplomacy and internal communication include occluded genres, which are difficult to access due to the nature of political and diplomatic activities (i.e. backstage negotiations, secrecy in communication, security issues).

\subsection{Languages in IR genre practices}

The traditional belief that French is the language of diplomacy was undermined by the academic and professional genre practices of our participants. According to the interviewees, English is undoubtedly the lingua franca of modern IR. However, the systematic overview of the IR genres in different languages showed that the interviewees' genre practices are characterised by distinct patterns of multilingualism.

All the interviewees reported using two or three languages in their daily academic or professional life. The texts in their genre collections were in one of the three languages listed in Table 1: English, Slovene and French. Some of the genres (e.g. academic articles, international treaties, court decisions, brochures) were in all three languages, some of them were only in one language. As expected, the most widely used sources in the academic environment were in English, while the genres in French were mostly limited to the primary sources. The cultural or linguistic specificities were also reflected in the names of genres: for some of them, our interviewees could not find any corresponding genres in other languages (e.g. galop d'essai, mémoire, déroulé). Consequently, the names of these genres were not translated. The culture specific genres appeared in two types of situations: in academic genres of exchange students and in genres of bilateral diplomacy.

The patterns of multilingual genre use were further complicated by the fact that even the same types of genres were actually regulated by different sets of rules when the interviewees used them in different languages. The interviews shed light on how different types of users participate in them across languages. A critical genre in this respect was one of the most widely used genres in academic contexts: the essay. The participants gave us detailed accounts of how they developed their essay writing competence in different 
languages and pointed out that it was very difficult for them to find their own authorial voice while following the rules of the genre in different linguistic contexts.

The complex linguistic identities of our interviewees also contributed to the ways they made their genre choices. Apart from the three languages listed in Table 1, our participants relied on additional languages in their language repertoires (i.e. German, Italian, Spanish, Croatian, Russian) to maximise the impact of their genre practices. The reason why the data on the genres in other languages was not included in Table1 lies in the fact that these languages are either not used by most of the participants, or they are not used in the most foregrounded genre practices. Beyond the institutional requirements, our interviewees explained that the choice of language in which a genre was enacted often depended on their general language competence and their appreciation of that of the other participants.

The specific types of genres used in different languages, and the strategic choices of languages, thus upgrade and nuance the image of English-only genre configurations in IR academic and professional practices. The evidence from our interviews shows that the IR students should learn how to deal with numerous genres, which form complex genre ecologies, varying across specific cultural, linguistic and institutional contexts. This means that written IR genres in one language cannot be seen as a transliterated copy of genres in another.

Being acquainted with the genres of a discourse community is important for each of its members, because the control of the genre repertoires enables full participation in the activities of the community (Martin and Rose 2008). Previous studies have highlighted the benefits of explicit teaching about genres (Bhatia 2008; Martin and Rose 2008; Gentil 2011; Galante et al. 2019), revealing evidence that students' knowledge about genre practices translates into better genre performance (Bawarshi and Reiff 2010).

This study aimed to shed light on the nature of genre practices of the IR community in order to provide an empirical basis which would lead to explicit teaching about the IR genres. In the first stage of our research we tried to establish a map of genres used by the IR community. By exploring the genre collections of our participants and analysing the semi-structured interviews with members of the target community we got a user perspective on the configurations of genre repertoires and the challenges faced by the users while struggling to use these.

The field-specific and professional genres collected by the interviewees covered a mixture of diverse genre families, which can be broadly subdivided into the academic genres and those of professional settings. Against the backdrop of internationalisation, the curriculum genres, which enable students to engage in their academic activities, are also moulded by the specific cultural and institutional contexts. The participants in 
professional settings were engaged in diverse activities stemming from administrative, diplomatic, journalistic, and public relations tasks. These tasks are influenced by global as well as by local cultural practices.

Based on the results of the genre mapping we can conclude that the rich genre repertoires used by the IR community members form complex multilingual genre ecologies. There is a clear continuity in the use of the genre repertoires in the academic and professional settings. However, some important gaps in the genre competence of our interviewees were identified as the members of the IR community moved to higher levels of academic competence and to professional contexts, namely: (1) the lack of preparedness for linguistically, culturally and institutionally imposed norms of genre; (2) few opportunities to engage with the genres of digital environment; and (3) the problems with access to the occluded and para-professional genres.

Our second research question dealt with the languages in which the IR genres were enacted. The rich plurilingual character of the IR genre practices emerged in the process of genre mapping. Even though our analysis started off with the aim of designing a genrebased FSP course, which would highlight those practices of the IR community that are typically enacted in French, we had to abandon the narrow perception of the language lenses. Within the genre families we have identified it is difficult to isolate and prioritise only the genres of one language, because multilingualism transforms the communication needs of the IR users, even when they work in essentially monolingual settings.

Signs of internationalisation of academic practices with English as a lingua franca are clearly discernible in the Slovene and in internationally-based IR communities. Similarly to academic contexts, the trend towards internationalisation in IR professional settings results in more and more English-dominated genre repertoires. Genre competence in a second, third or even fourth language is required for successful participation in IR professional settings.

Triangulation with course programmes showed that the official language policies of the institutions in which our interviewees were integrated, as well as participants' microdecisions, influenced the genre practices and choice of languages in concrete situations. But unlike some multilingual students, who felt that their language repertoires were constrained by the effects of internationalisation (Meyer et al. 2012), our respondents actively sought to explore the richness of their plurilingual profiles to maximise the impact of their genre practices.

With reference to the analysis of the changes that occur in the genre repertoires of the IR community members, our study highlights the fact that acculturation in a discourse community is a long process, in which the academic setting serves as a preparation for efficient workplace genre practices. What the IR community members are facing in their daily genre realities are active multilingualism, relative instability, complexity and unpredictability of genre practices. All these characteristics of genres can produce additional stress on the novice members of the discourse community and on genre users 
moving from one institutional context to the other, in particular when they have not been prepared to deal with these realities.

Furthermore, we found out that the genres and genre families in the genre ecologies of the IR community have been transformed as the disciplinary genre practices evolved during the last two decades. These changes could be attributed to the impact of the Bologna reform and to the growing digitalisation of IR communication.

\subsection{Implications for LSP research and LSP teaching}

Beyond the description of genre repertoires, the interplay of genres in the genre ecologies and the evolution of genre practices in IR open some questions that were presented as resolved in LSP theory and practice, namely the questions of genre users' linguistic identities and their navigation through genres.

The theoretical implications of the findings refer to the need to broaden the prevailing ESP perspectives on the acquisition of genre knowledge in academic settings. ESP focuses on specific genres within spheres of activity, such as the medical profession, and aims to develop non-native speakers' genre competence in the English language by relying on the broader concept of communicative purposes, which are targeted by the users of a genre. The theory of genres stems from this perspective.

The case of the IR community members shows that academic and professional internationalisation, as well as the target needs of internationally oriented communities, call for a more complex approach to the theory of genres. This approach should strive to account for the multilingual users' perspective in which the question of native speakers' language problems should not be the only concern of the LSP teachers. The broadened genre theory should integrate a multicultural social reality of academic and professional settings. The data from the interviews therefore aligns with the calls for a revised conceptualisation of genre-based knowledge (Sommer Farias et al. 2020). The findings also have some immediate and long-term implications for LSP teaching.

Our study confirms that LSP teaching should go beyond the traditional work with texts. Rather than analysing the text structure or simply describing ways in which a language 'works', it should strive to help community members better navigate their academic and professional activities.

Firstly, the results indicate that the teachers aiming to facilitate learning about the IR community genres should become more flexible in the choice of genre types to account for new genres, e.g. the genres of social media. The focus on isolated high-stakes genres, such as research articles, should be broadened by the concept of genre ecologies. As explained by the genre users of the IR community, a combination of genre families contributes to the unique constellation of genre practices, which reflect the community culture, relations among the members, and effective functioning of the community. Teachers should therefore extend the genre repertoires presented to the students. To facilitate 
the acculturation processes, novices in the community or students entering an academic institution in a French-speaking context would need a more broadly oriented course that would address not only the purely linguistic aspects, but also the cultural and political situatedness of genre practices, including information on the national teaching and learning traditions. These findings corroborate the recent theoretical advances and efforts to enrich students' language learning experience with activities aimed at the development of mediation, plurilingual and pluricultural competence (Council of Europe 2020).

Secondly, the phenomena of continuity and discontinuity in genre practices of the IR community should be dealt with as part of the genre awareness activities.

Thirdly, the segmentation of the participants' academic and professional trajectories, which is due to issues of linguistic, disciplinary and institutional complexity, requires a more holistic and coordinated approach to genre building practices. The students' and professionals' role in disclosing the nature of genre ecologies is central in this. By becoming informants and partners in research, they can contribute to a well-planned genrebased approach and improve their own genre awareness. Given the proliferation of different genres in different languages, synergies should be sought, not only on the level of LSP courses but also on the institutional level. This would require a repositioning of LSP courses in the IR curricula. Such a repositioning does not necessarily imply that new teaching models should be imposed on LSP teaching, but it sets new tasks on the agenda of LSP research and practice, including tighter collaboration between LSP and IR disciplinary teachers.

\section{5}

\section{CONCLUSION}

We have attempted to analyse the genre practices of the IR community to establish the nature of the genre repertoires used by different profiles of community members in academic and professional contexts. The study adds to a growing body of evidence on genres in different disciplinary settings. It proves that genre mapping can be useful as a method to detect cultural specificities, but it remains an insufficiently used tool.

Having outlined the main characteristics of the genre repertoires in the IR community, we can conclude that the complexity and variety of the IR genre ecologies were the recurring themes in all the stages of our analysis. The design of an LSP programme that would take into account these two characteristics of genre practices in the international community would require a careful selection of key partners, long-term introduction of new pedagogical concepts, and adaptation of existing teaching strategies.

The limitations of our study stem from the choice of the method, and from the selection of our participants. The accounts of genre practices were valuable, because they revealed data which would otherwise remain uncovered. However, the participants' responses were susceptible to recall bias, in particular when they reflected on the use of 
genres in the past. Secondly, in the scope of our study, the participant data could only contextualise the genre practices linked to the disciplinary practices of Slovene-based members of IR community. Our analysis of IR genre ecologies can therefore be seen as a starting point for a comprehensive analysis of multilingual practices in the IR community. Finally, more research would be needed to find out how multilingual genre tasks can help students work within and across genres in different languages, and how they can encourage a more context-based genre teaching and learning.

\section{LITERATURE}

ANGOURI, Jo (2014) Multilingualism in the workplace: Language practices in multilingual contexts. Multilingua - Journal of Cross-Cultural and Interlanguage Communication, 33(1-2), 1-9.

BAWARSHI, Anis S./Mary Jo REIFF (2010) Genre: An introduction to history, theory, research, and pedagogy. Parlor Press West Lafayette, IN.

BAZERMAN, Charles (1994) Systems of genres and the enactment of social intentions. Freedman A, Medway P (eds.) Genre and the New Rhetoric. Taylor \& Francis, London, 79-101.

BHATIA, Vijay K. (2008) Genre analysis, ESP and professional practice. English for specific purposes, 27(2), 161-174.

BLOMMAERT, Jan/James COLLINS/Stef SLEMBROUCK (2005) Spaces of multilingualism. Language \& Communication, 25(3), 197-216.

CANAGARAJAH, Suresh (2007) Lingua franca English, multilingual communities, and language acquisition. The modern language journal, 91, 923-939.

CANAGARAJAH, Suresh (2018) Translingual practice as spatial repertoires: Expanding the paradigm beyond structuralist orientations. Applied Linguistics, 39(1), 31-54.

CHANG, Sin-Yi (2019) Beyond the English Box: Constructing and Communicating Knowledge Through Translingual Practices in the Higher Education Classroom. English teaching \& learning, 43(1), 23-40.

CHITEZ, Madalina/Otto KRUSE (2012) Writing cultures and genres in European higher education. University writing: Selves and texts in academic societies. Brill, 151-175. COUNCIL OF EUROPE (2001) Common European Framework of Reference for Languages: Learning, teaching, assessment. Cambridge: Cambridge University Press / Council of Europe.

COUNCIL OF EUROPE (2020) Common European Framework of Reference for Languages: Learning, teaching, assessment - Companion volume, URL: https:// $\mathrm{rm}$.coe.int/common-european-framework-of-reference-for-languages-learningteaching/16809ea0d4.

EUROPEAN COMMISSION (2009) The Bologna Process 2020 - The European Higher Education Area in the new decade Communiqué of the Conference of European 
Ministers Responsible for Higher Education, Leuven and Louvain-la-Neuve, 28-29 April 2009.

FRANCESCHINI, Rita (2011) Multilingualism and multicompetence: A conceptual view. The Modern Language Journal, 95(3), 344-355.

FROW, John (2006) Genre. Routledge.

GALANTE, Angelica et al. (2019). Plurilingualism in higher education: A collaborative initiative for the implementation of plurilingual pedagogy in an English for academic purposes program at a Canadian university. TESL Canada Journal, 36(1), 121-133.

GENTIL, Guillaume (2011) A biliteracy agenda for genre research. Journal of Second Language Writing, 20(1), 6-23.

HYON, Sunny (1996) Genre in three traditions: Implications for ESL. TESOL quarterly, 30(4), 693-722.

JARC, Mojca (2015) “Zdaj morate pozabit vse, kar ste se prej naučili”: gradnja medkulturnih kompetenc pri slovenskih študentih nefilološke fakultete $\mathrm{v}$ frankofonem akademskem okolju. Journal for Foreign Languages, 7(1), 169-189.

KIM, Minkyung/Diane BELCHER (2018) Building genre knowledge in second language writers during study abroad in higher education. Journal of English for Academic Purposes, 35, 56-69.

KRUSE, Otto/Madalina CHITEZ (2012) Contrastive genre mapping in academic contexts: An intercultural approach. Journal of Academic Writing, 2(1), 59-73.

LEBOW, Richard Ned (2008) A cultural theory of international relations. Cambridge University Press.

LILLIS, Theresa (2013) Sociolinguistics of writing. Edinburgh University Press.

LORENZO, Francisco (2013) Genre-based curricula: multilingual academic literacy in content and language integrated learning. International Journal of Bilingual Education and Bilingualism, 16(3), 375-388.

MARTIN, James R./David ROSE (2008) Procedures and Procedural Recounts. Genre Relations: Mapping Culture. London: Equinox.

METTEWIE, Laurence/Luk VAN MENSEL (2009) Multilingualism at all costs: Language use and language needs in business in Brussels. Sociolinguistica, 23(1), 131-49.

MEYER, Stephan, et al. (2012) Plurilingualism, multilingualism and internationalisation in the European Higher Education Area: Challenges and perspectives at a Swiss university. Language Learning in Higher Education, 2(2), 405-425.

MOORE, Danièle/Laurent GAJO (2009) Introduction-French voices on plurilingualism and pluriculturalism: Theory, significance and perspectives. International Journal of Multilingualism, 6(2), 137-153.

NORTON, Bonny (2010) Language and identity. Sociolinguistics and language education, 23(3), 349-369.

ORLIKOWSKI, Wanda J./JoAnne YATES (1994) Genre repertoire: The structuring of communicative practices in organizations. Administrative science quarterly, 541-574. 
PIERINI, Francesco (2016) Multilingualism and Englishization in international business communication: the case of some Italian wine producers. English Today, 32(1) 48-55. ROCHE, Jean-Jacques (2001) Théories des Relations Internationales. Paris: Montchrestien. SCHLABACH, Joachim (2017) Probleme in mehrsprachigen Situationen. Zur Grundlegung des Lernziels plurilinguale Kompetenz. Zeitschrift für interkulturellen Fremdsprachenunterricht, 22(2), 66-79.

SOMMER-FARIAS, Bruna/Christine M. TARDY/Jeroen GEVERS (2020) Teaching and Researching Genre Knowledge: Toward an Enhanced Theoretical Framework. Written Communication, 37(3), 287-321. https://doi.org/10.1177/0741088320916554.

\section{POVZETEK}

\section{VEČJEZIČNE ŽANRSKE PRAKSE V MEDNARODNIH ODNOSIH}

Med posledice globalizacije štejemo ne samo tesnejše, ampak tudi jezikovno kompleksnejše komunikacijske mreže. Večjezične prakse so spremenile akademsko in poklicno življenje, s tem pa so pred učence in učitelje tujih jezikov stroke (TJS) postavile nove zahteve. Pričujoči članek v ospredje postavlja vprašanje rabe žanrov v večjezičnih globaliziranih kontekstih. Žanri so bili prepoznani kot ena od osrednjih tematik poučevanja TJS. Čeprav so predhodne raziskave pokazale, da morajo člani diskurzne skupnosti usvojiti primerne žanrske prakse, značilne za strokovno področje, na katerem delujejo, je malo znanega o naravi žanrskih repertoarjev na področju mednarodnih odnosov (MO). V članku poročamo o kvalitativni raziskavi žanrskih praks v diskurzni skupnosti MO. Namen naše raziskave je bil ugotoviti, katere značilne žanrske repertoarje uporabljajo člani te skupnosti v akademskih in poklicnih okoljih. Osredotočamo se na jezike, v katerih so žanri udejanjeni, in na spremembe $\mathrm{v}$ žanrskih praksah, ki se pojavijo kot posledica prehajanja članov skupnosti v različne akademske in poklicne ali institucionalne kontekste. Analiza zbirk žanrov in podatkov, zbranih v polstrukturiranih intervjujih s študenti, profesorji in diplomanti MO, razkriva bogastvo, raznolikost in asimetrične vzorce žanrske rabe $\mathrm{v}$ treh jezikih: francoščini, slovenščini in angleščini. Raziskava nakazuje, da se je strokovno sporočanje naših intervjuvancev v zadnjih dvajsetih letih močno spremenilo in da spremembe $\mathrm{v}$ žanrskih ekologijah zahtevajo nove pristope $\mathrm{k}$ poučevanju o žanrih. Na temeljih izsledkov raziskave razpravljamo o izzivih večjezične stvarnosti za učitelje TJS in za raziskovalce žanrov.

Ključne besede: TJS, večjezičnost, žanrski repertoar, žanrska ekologija, žanrska praksa, mednarodni odnosi 


\begin{abstract}
Globalisation has produced not only denser, but also linguistically more complex communication networks. Multilingual practices have transformed the academic and professional lives of language learners, and imposed new requirements on LSP teaching. This article foregrounds genres in multilingual globalised contexts. Genres have been recognised as one of the key focuses of LSP. Although previous research highlighted the importance of developing relevant field-specific genre practices, little attention has been paid to the nature of genre repertoires in the field of International Relations (IR). We report on the findings of a qualitative study into genre practices of the IR community. We set out to examine the typical genres of IR in academic and in professional settings. We focus on the languages in which these genres are enacted, and on the transformation of genre practices that occurs as a result of the community members' trajectories through different academic and professional or institutional contexts. The analysis of genre collections and of the data collected through semi-structured interviews with IR students, professors, and graduates, reveals the rich, diverse, and asymmetrical patterns of genre use in three languages: French, Slovene, and English. The study suggests that the informants' disciplinary communication has changed considerably over the past twenty years, and that the changes in the genre ecologies require new approaches to teaching about genres. Based on the findings of the study, the paper discusses the challenges of multilingual realities for LSP teachers and genre analysts.
\end{abstract}

Keywords: LSP, multilingualism, genre repertoire, genre ecology, genre practice, International Relations 